\title{
Geostatistics application in spatial analysis of geomechanical properties
}

\author{
Ta Quoc Dung, Vu Duc Thinh
}

\begin{abstract}
Geomechanics applications play an important role in both drilling and production of oil and gas field. There are many important properties such as Unconfined compression strength (UCS), Poison ratio (PR), Internal Friction Coefficient (IF) and Porosity (PHIE) need to be estimated properly. To estimate these properties, there are many methods that can be used but geostatistics has more advantages. This research presents geomecanical propertiesfor two offset wells according to experiment relations existing. Then, variogramand spatial continuity will be analyzed. The OrdinaryKriging (OK) methods will be used to interpolatethe properties in the cross section between two offset wells and then for a planned well. The predicted properties were compared with the actual measured data to find the linear correlation coefficient. Most of these values arenearly 1 . As a result, the quality of the modelbuilt could be practically accurate and reliable to predict geomechanical properties for planned wells used in wellbore stability, sanding studies.
\end{abstract}

Index Terms - Geostatistics, Variogram, Kriging, Geomechanics Model, WellboreStability.

\section{INTRODUCTION}

$\mathrm{T}$ The better understanding and demand of accurate geomechanicial properties are vital for wellbore stability analysis, sand control and other geomechanics applications. These properties are primarily calculatedbased on petrophysical data, then calibrated where possible against limited

Manuscript Received on August 7th, 2017. Manuscript Revised December 25th, 2017

This research is funded by Ho Chi Minh City University of Technology - VNU-HCM, under grant number C2017-20-25.

Ta Quoc Dung - Faculty of Geology and Petroleum Engineering, Ho Chi Minh city University of Technology VNU-HCM (e-mail: tqdung@hcmut.edu.vn).

Vu Duc Thinh - Faculty of Geology and Petroleum Engineering, Ho Chi Minh city University of Technology VNU-HCM.

* Corresponding author: Email: tqdung@ @cmut.edu.vn core data. There are a number of empirical correlations that can be used for calculation, suitable for various rock type, age, depth range and field. In 2009, Khaksar et al [2] presenteda variety of published log-core strength correlations for rock strength modeling and combined with some applications of computing technique such as fuzzy logic and cluster pattern recognition. This combination, coupled also with sedimentary facies analysis can improve rock strength estimation. However, similar to other conventional geomechanics studies, the results shown estimated geomechanical properties with depth-stretched method that is equivalent to correlation in petrophysics study. The other study and papers currently are still used the same workflow with applying correlation and choosing the closest well for estimation geomechanical properties [8, 11]. In oil price downturn situation, it is more difficult to drill new exploration wells and challenge to drill successfully. Furthermore, the geologic pattern has become more complex and extremely risky. In addition, the budget for core test also reduced and limited. Because of insufficiency of information required, right access to a method capable to determine properly geomechanics information on the existing information is highly interested. This study will utilized the concepts of variogram, krigingand spatial analysisto predict geomechanics properties with high accuracy. The properties used in this study are: Unconfined compression strength (UCS), Poison ratio (PR), Internal Friction Coefficient (IFC) and Porosity (PHIE).

\section{FUNDAMENTAL THEORY}

\section{$2.1 \quad$ Geostatistics estimation}

Geostatistics offers a way of characterizing the spatial continuity of natural phenomena by analyzing them as random variables [1]. Geostatistics can describe data distribution in various spatial directions. This technique is suitable for heterogeneity of the reservoir hence 
geostatistics has been seen as the core hypothesis for model generation in major modeling software like Petrel (Slb), RMS (Roxar) [2]. Basic components of Geostatistics are variogram and Kriging techniques.

\subsection{Variogram and Covariance}

Variogram is a mathematical function, basic tool to quantify correlation of spatial variables [1], defined as:

$$
\begin{gathered}
2 \gamma(h)=E\left\{[Z(u+h)-Z(u)]^{2}\right\} \\
\gamma(h)=\frac{1}{2 N(h)} \sum_{i=1}^{N}[Z(u)-Z(u+h)]
\end{gathered}
$$

Where:

- h: Lag Distance

- N(h): Total number of pairs for lag $h$

- $\gamma(h):$ Variogram

- $\mathrm{Z}(\mathrm{u})$ and $\mathrm{Z}(\mathrm{u}+\mathrm{h})$ : Head and tail value for pair i.

There are three standard variogram models: Spherical, Exponential and Gaussian. In practice, we need to replace empirical variogram with a most matched variogram model.

Covariance measures similar variation of 2 random variables, defined as:

$$
C(h)=\mathrm{E}\{\mathrm{Z}(\mathrm{u}+\mathrm{h}) \mathrm{Z}(\mathrm{u})\}-[E\{\mathrm{Z}(\mathrm{u})\}]^{2}
$$

And obeyed the following relationship:

$$
C(h)=C(0)-\gamma(\mathrm{h})
$$

Where:

$$
\begin{aligned}
& C(0)=\mathrm{E}\{\mathrm{Z}(\mathrm{u}+0) \mathrm{Z}(\mathrm{u})\}-[E\{\mathrm{Z}(\mathrm{u})\}]^{2} \\
& =E\left\{\mathrm{Z}(\mathrm{u})^{2}\right\}-[E\{\mathrm{Z}(\mathrm{u})\}]^{2}=\sigma^{2}
\end{aligned}
$$

\subsection{Kriging:}

Kriging is a geostatistical technique for optimally interpolating values at unsampled locations. Kriging employs variogram model, so it is a weighted method with respect to both distance and trend of data. It generates Best Linear Unbiased Estimation (BLUE) at each location.

Simple Kriging (SK): The simplest kriging and rarely applied in reality. Global mean is assumed known and constant in the study area, which is not really actual [2]. The value at an unsampled location can be estimated by:

$$
\begin{gathered}
Z *\left(u_{0}\right)=\lambda_{0}+\sum_{i=1}^{n} \lambda_{i} \cdot Z\left(\mathrm{u}_{i}\right) \\
l_{0}=m\left(1 \sum_{i=1}^{n} l_{1}\right)
\end{gathered}
$$

$\lambda_{\mathrm{i}}$ are calculated from minimum variance condition, as below simplified covariance matrix:

$$
\sum_{j=1}^{n} l_{j} C\left(u_{i}, u_{j}\right)=C\left(u_{i}, u_{0}\right) 1, \ldots, n
$$

Where:

- $\mathrm{Z}^{*}\left(\mathrm{u}_{0}\right)$ : Estimated value at location $\mathrm{u}_{0}$.

- $Z\left(u_{i}\right)$ : Nearby sample value at location $u_{i}$.

- $n$ : Total number of samples selected in the study area.

- $\lambda_{\mathrm{i}}$ : Weights assigned to each sample

$-\lambda_{0}=$ a constant

- m: Global mean value in area .

- $\mathrm{C}\left(\mathrm{u}_{\mathrm{i}}, \mathrm{u}_{\mathrm{j}}\right)$ : Covariance value between points located at $\mathrm{u}_{\mathrm{i}}$ and $\mathrm{u}_{\mathrm{j}}$.

- $\mathrm{C}\left(\mathrm{u}_{\mathrm{i}}, \mathrm{u}_{0}\right)$ : Covariance between sampled location $\mathrm{u}_{\mathrm{i}}$ and unsampled location $\mathrm{u}_{0}$

Ordinary Kriging (OK): Assuming that there are many local means and calculated from nearby values [2]. This also assumes true global mean is unknown so it is "ordinarily" used more than SK. The estimation is written as:

$$
Z^{*}\left(u_{0}\right)=\sum_{i=1}^{n} \lambda_{i} \cdot Z\left(u_{i}\right)
$$

$$
\sum_{i=1}^{n} \lambda_{i}=1 \text { or } \lambda_{0}=0
$$

By forcing $\lambda_{0}$ to be zero, the necessity of mean $m$ is eliminated which constitutes Eq.(6) by Eq.(9)

$\lambda_{\mathrm{i}}$ are calculated from minimum variance condition, as below simplified covariance matrix:

$$
\begin{gathered}
\sum_{j=1}^{n} \lambda_{j} C\left(u_{i}, u_{j}\right)+\mu=C\left(u_{i}, u_{0}\right) \\
\mathrm{i}=1, \ldots, \mathrm{n}
\end{gathered}
$$

Where $\boldsymbol{\mu}$ is Lagrange parameter.

CoKriging: Cokriging is used to estimate one variable value with co-variable. Two common examples are the estimation of permeability using porosity data and the estimation of porosity data using seismic data [1]. Estimation equation is: 


$$
\begin{gathered}
Z^{*}\left(u_{0}\right)=\sum_{i=1}^{n} \lambda_{Z_{i}} \mathrm{Z}\left(u_{Z_{i}}\right)+\sum_{k=1}^{m} \lambda_{Y_{k}} \mathrm{Y}\left(u_{Y_{k}}\right) \\
\sum_{i=1}^{n} \lambda_{Z_{i}}=1 \text { and } \sum_{k=1}^{m} \lambda_{Y_{k}}=0
\end{gathered}
$$

$\lambda_{Z_{i} \text { and }} \lambda_{Y_{k}}$ are calculated from minimum variance condition, as below covariance matrix:

$$
\begin{aligned}
& \sum_{j=1}^{n} \lambda_{Z_{j}} \mathrm{C}_{Z}\left(u_{Z_{i}}, u_{Z_{j}}\right)+\sum_{k=1}^{m} \lambda_{Y_{k}} \mathrm{C}_{C}\left(u_{Z_{i}}, u_{Y_{k}}\right)+\mu_{Z} \\
& =C_{Z}\left(u_{0}, u_{Z_{i}}\right) ; \mathrm{i}=1, \ldots, n . \\
& \sum_{i=1}^{n} \lambda_{Z_{i}} \mathrm{C}_{C}\left(u_{Z_{i}}, u_{Y_{i}}\right)+\sum_{l=1}^{m} \lambda_{Y_{l}} \mathrm{C}_{Y}\left(u_{Y_{k}}, u_{Y_{l}}\right)+\mu_{Y} \\
& =C_{C}\left(u_{0}, u_{Y_{k}}\right) ; \mathrm{k}=1, \ldots, \mathrm{m} .
\end{aligned}
$$

Where:

- $\lambda_{Z_{i}}$ : weights assigned to $Z\left(u_{Z_{i}}\right)$ at $u_{Z_{i}}$

- $\lambda_{Y_{k}}$ : weights assigned to $\mathrm{Y}\left(u_{Y_{k}}\right)$ at $u_{Y_{k}}$

- $\mathrm{C}_{\mathrm{Z}}$ and $\mathrm{C}_{\mathrm{Y}}$ : covariance for the $\mathrm{Z}$ and $\mathrm{Y}$ variables, respectively.

- $\mathrm{C}_{\mathrm{C}}$ : Cross-variance between 2 variables. $\mu_{\mathrm{Z}}$ and $\mu_{\mathrm{Y}}$ : Lagrange parameters.

\section{GEOMECHANICAL $M O D E L$}

The geomechanical properties were calculated from correlations based on well-logging data. Then, core and experiments data were used to calibrate.

Unconfined compressive strength:

Unconfined compressive strength is defined as the maximum axial compressive strength that a right-cylindrical sample can withstand under unconfined conditions. There are many correlations to determine UCS based on seismic and well logging data. This study used MsNally's correlation which can be applied for sand reservoir [3].

$$
U C S=185165 * \exp (-0.037 * D T C)
$$

Poisson's ratio:

Defined as the ratio of transverse contraction strain to longitudinal extension strain in the direction of stretching force, calculated based on velocity $\log [4]$

$$
v=\frac{v_{p}^{2}-2 v_{s}^{2}}{2\left(v_{p}^{2}-v_{s}^{2}\right)}=\frac{0.5\left(\frac{D T S}{D T C}\right)^{2}-1}{\left(\frac{D T S}{D T C}\right)^{2}-1}
$$

Internal friction coefficient (IFC): IFC measures the ability of an unit rock or soil to with stand a shear stress, calculated based on velocity $\log$ $I F C=\tan \left(a \sin \left(\frac{\frac{v_{p}}{1000}-1}{\frac{v_{p}}{1000}+1}\right)\right) \quad$ if $V c l>0.7$ $I F C=\tan \left(\frac{3.14 \times\left(\frac{17.232 \times v_{p}}{1000}\right)^{3.51}}{185}\right) \quad$ if $V c l<0.7$

Porosity (PHIE):

PHIE were calculated based on correlation with UCS [3]:

$$
P H I E=-0.1 \ln \left(\frac{U C S}{20144}\right)
$$

Where:

- $\mathrm{v}_{\mathrm{p}}$ : Compressional wave velocity

- $\mathrm{v}_{\mathrm{s}}$ : Shear wave velocity

- DTC: Compressional wave travel time ( $\mu \mathrm{s} / \mathrm{ft}$ )

- DTS: Shear wave travel time $(\mu \mathrm{s} / \mathrm{ft})$, Vcl: Clay volume

\section{ROCK PROPERTIES PREDICTION}

\subsection{Prediction workflow}

Step 1: Building geomechanical models

- Getting the input - petrophysical data (velocity and density)

- Build geomechanical models for along the offset wells by using the above empirical correlations.

- Validate rock properties estimated with core samples.

Step 2: Building variogram models

- Calculating experimental variogram for the cross section based on the data between 2 offset wells,

- Choosing the standard variogram models.

- Cross-validating to find the best-fit variogram model for each property.

Step 3: Predicting geomechanical model

Using chosen variogram models to interpolatethe 2D geomechanical model between 2 offset wells and then for the planned well using Ordianary Kriging (OK). 


\subsection{Geomechanics model and results}

Petrophysics offset data from field A of Cuu Long basin, Vietnam is used in this research to build geomechanics model along the well path. The study presented the fundamental ideas of geostatistics for interpolating the geomechanics detail of the area with the boundaries from 2 offset well: XX-2P and XX-3P (Figure 1). The distance between two offset wells is about $2.6 \mathrm{~km}$. Estimated points are compared with the actual points based on regression value and coefficient of correlation.

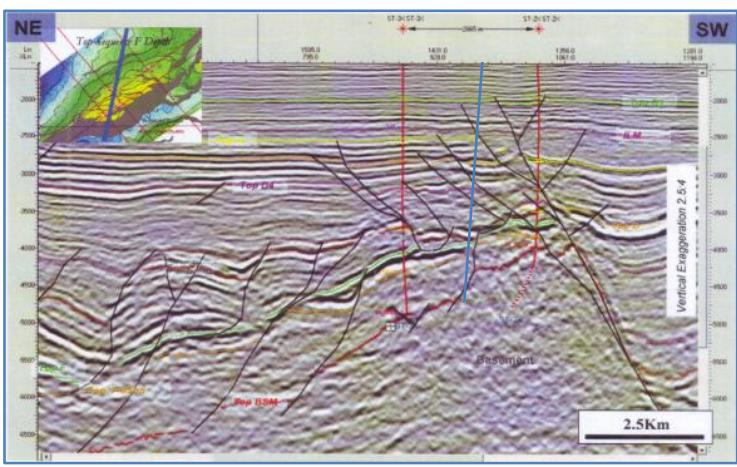

Figure 1. The cross section between 2 offset wells, field A

Building geomechanical models

The input data from $\mathrm{XX}-2 \mathrm{P}$ and $\mathrm{XX}-3 \mathrm{P}$ included: velocity (DTC, DTS) and density log (Rho). Because DTC data just only for the section (3470m $-4247 m)$, so we must combine with the velocity $\log (\mathrm{Vel})$ from seismic $(\mathrm{Vp})$ to have a full DTC $\log$. Due to a more limited data of DTS, we ought to calculate the DTC-DTS regression to build the full DTS log. Similarly, density log cannot be measured for the whole wellbore. So that, we might use Garner's correlation to build density $\log$ based on velocity $\log$ for unmeasured well sections:

$$
R h o=0.24(\mathrm{vel})^{0.25}
$$

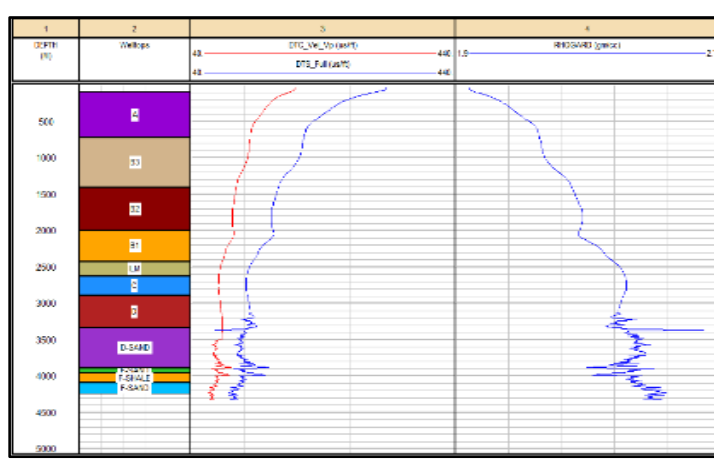

Figure 2. The input data for well $\mathrm{XX}-2 \mathrm{P}$

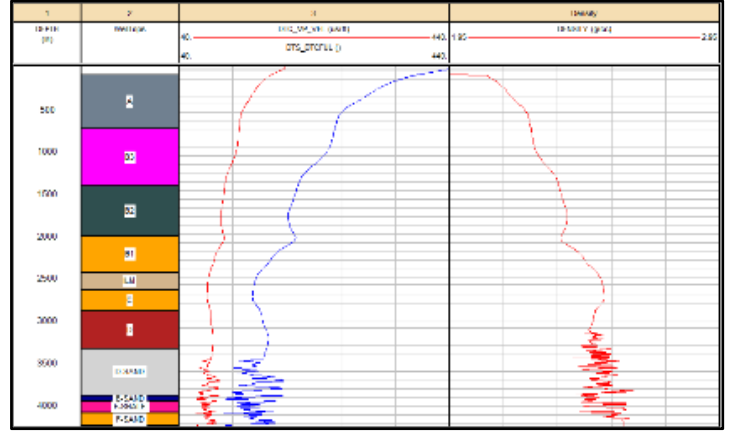

Figure 3. The input data for well XX-3P

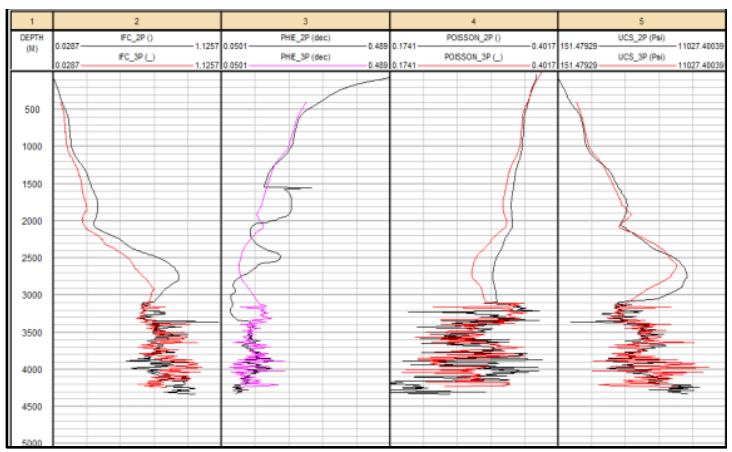

Figure 4. The geomechanical properties for XX-2P and XX-3P

Building variogram models: For each property, the unique experimental variograms for both of two wells were calculated, then checked with the standar variogram models. Overall, these variogram had a very good correlation coefficient (r2).

The above variogram model of UCS (Figure 4) is shown to be the best-fit with Gaussian model with $\mathrm{r} 2=99.7 \%$

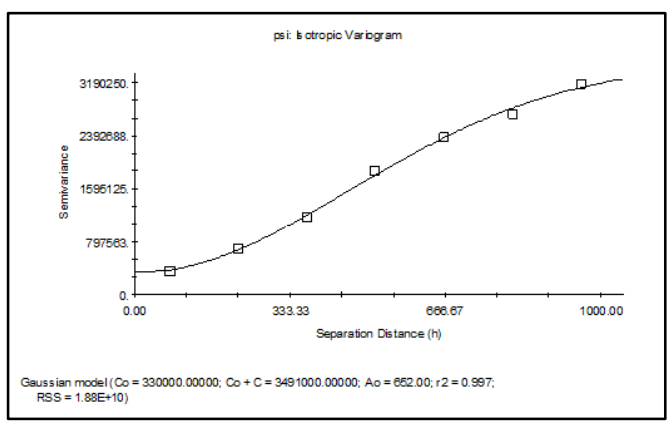

Figure 5. Variogram model for UCS 


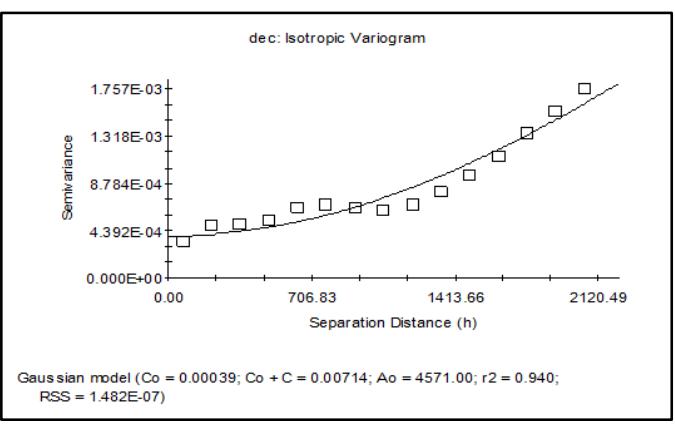

Figure 6. Variogram model for PR

The variogram model of PR (Figure 6) is shown to be the best-fit with Gaussian model with r2 $=94 \%$.

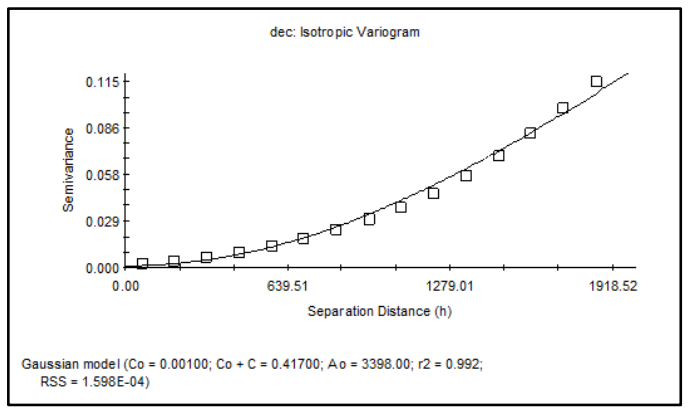

Figure 7. Variogram model for IFC

The variogram model of IFC (Figure 7) is shown to be the best-fit with Gaussian model with $\mathrm{r} 2=99.2 \%$.

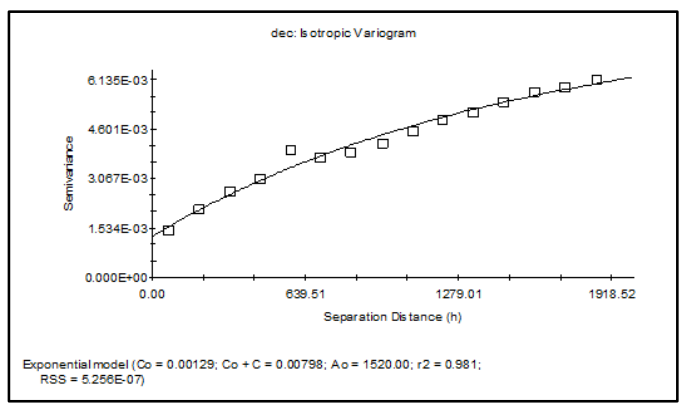

Figure 8. Variogram model for PHIE

The above variogram model of PHIE (Figure 8) is shown to be the best-fit as Exponential model with $\mathrm{r} 2=98.1 \%$.

Cross-validation for best-fit variogram model

Each of these variogram models was then used for cross-validated to evaluate the accuracy variogram model before applying Kriging techniques. To obtain the best-fit variogram, we may eliminate or edit some outliner points which may be due to invalid measurements. As shown below figures, all of correlation factors are higher than $95 \%$.

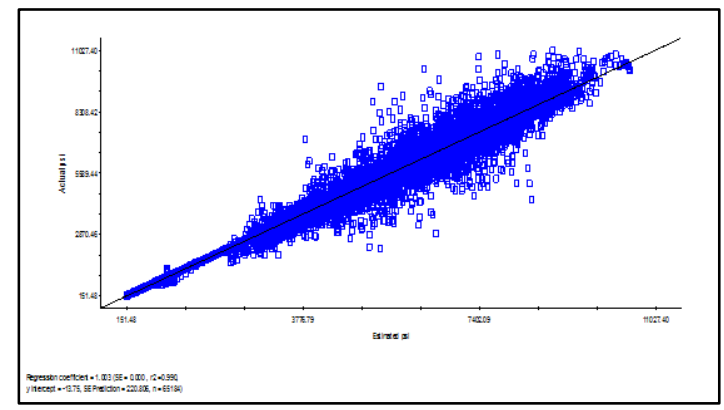

Figure 9. The cross-validation results of UCS

Cross-validated correlation factor (r2) of UCS equals to $99 \%$.

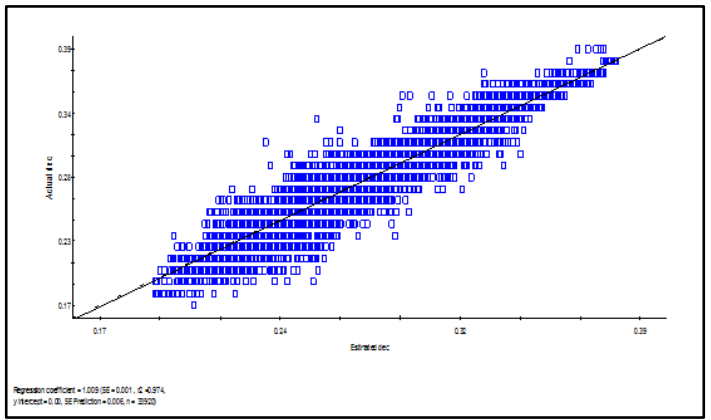

Figure 10. The cross-validation results of PR

Cross-validated correlation factor ( $\mathrm{r} 2$ ) of PR equals to $97.4 \%$

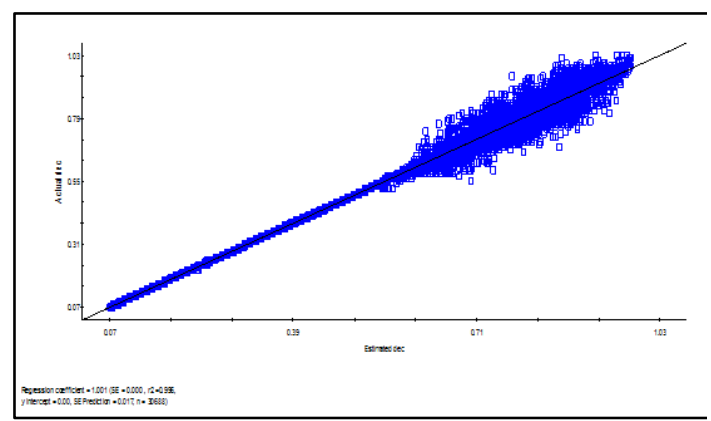

Figure 11. The cross-validation results of IFC

Cross-validated correlation factor $(\mathrm{r} 2)$ of $\mathrm{IFC}$ equals to $99.6 \%$. 


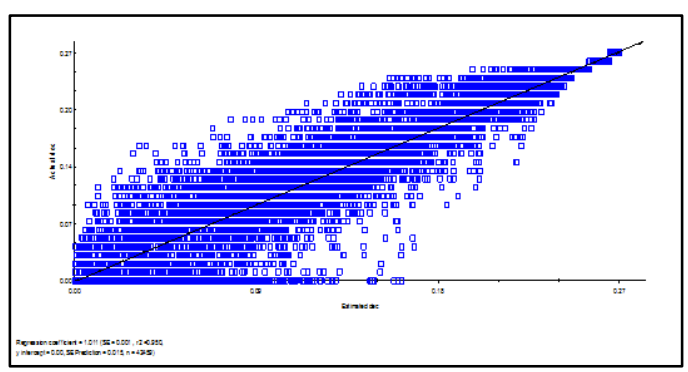

Figure 12. Thecross-validation results of PHIE

Cross-validated correlation factor (r2) of PHIE equals to $95 \%$

\section{Predicting geomechanical model}

The best-fit variogram models are used to predict geomechanical properties for well XX-4P.

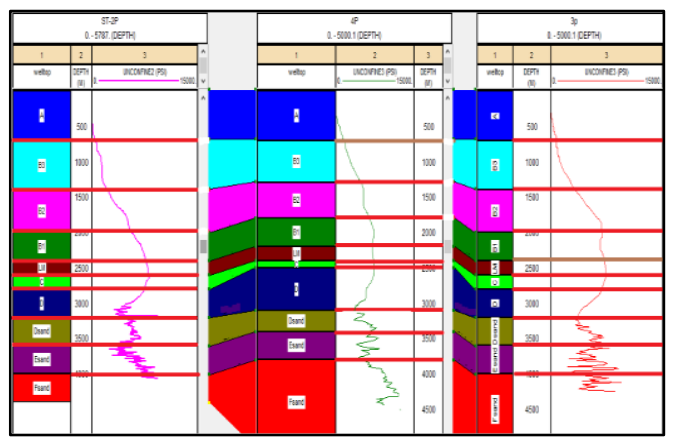

Figure 13. Well-correlation with UCS of XX-2P (in pink), $\mathrm{XX}-3 \mathrm{P}$ (in red) and predicted well $\mathrm{XX}-4 \mathrm{P}$ (in green)

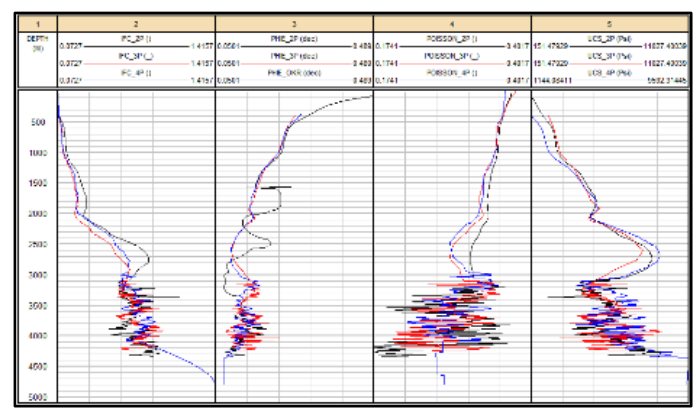

Figure 14. Predicted properties of well XX-4P (in black) compared with $\mathrm{XX}-2 \mathrm{P}$ (in red) and $\mathrm{XX}-3 \mathrm{P}$ (in blue)

\section{Cross-checking the predicted values}

To validate the model used for prediction, crosscheck is used for verifying all geomechanical properties. This process is used variogram model choosen to re-estimate all measured data.

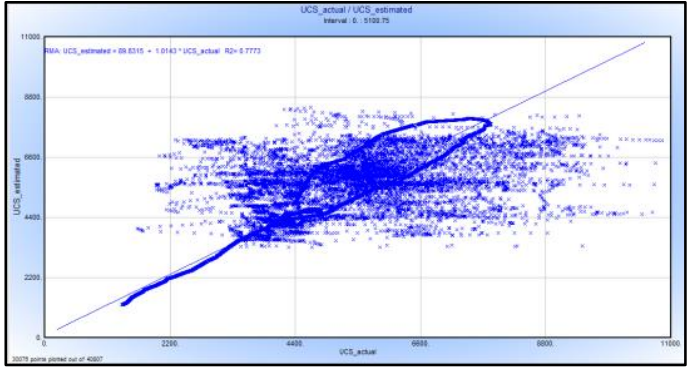

Figure 15. The cross-checking of UCS

Cross-checking UCS between actual and estimated values with $\mathrm{r} 2=77.73 \%$.

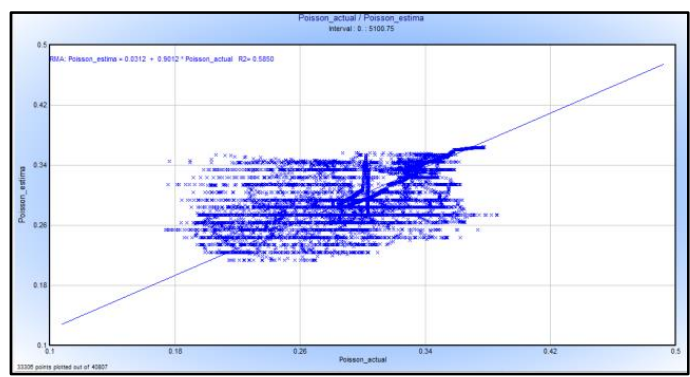

Figure 16. The cross-checking of PR

Cross-checking PR between actual and estimated values with $\mathrm{r} 2=58.5 \%$.

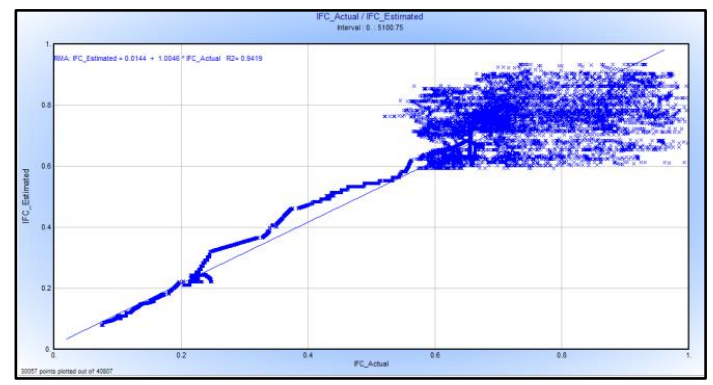

Figure 17. The cross-checking of IFC

Cross-checking IFC between actual and estimated values with $\mathrm{r} 2=94.19 \%$

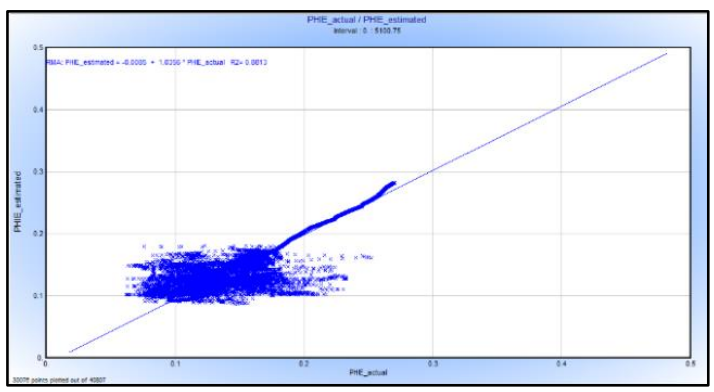

Figure 18. The cross-checking of PHIE 
Cross-checking PHIE between actual and estimated values with $\mathrm{r} 2=88.13 \%$.

\section{CONCLUSION}

In this study, geomechanical model has been studied using empirical correlations to calculate geomechanical properties of between two wells $\mathrm{XX}-2 \mathrm{P}$ and XX-3P from petrophysical data. Then geostatistics was applied to predict 2D geomechanical model between two offset wells and then the planned well $\mathrm{XX}-4 \mathrm{P}$, including properties: UCS, PR, IFC and PHIE. The best-fit variogram have been choose and validated as following tables.

TABLE 1

COMPARISON BETWEEN VARIOGRAM MODELS WITH $\mathrm{r} 2$ FOR EACH TYPES OF MODELS

\begin{tabular}{|c|c|c|c|c|}
\hline Properties & UCS & PR & IFC & PHIE \\
\hline Spherical & $96.90 \%$ & $83.30 \%$ & $90.10 \%$ & $95.90 \%$ \\
\hline Gaussian & $\mathbf{9 9 . 7 0 \%}$ & $\mathbf{9 4 . 0 0 \%}$ & $\mathbf{9 9 . 2 0 \%}$ & $97.20 \%$ \\
\hline Exponenial & $93.40 \%$ & $81.50 \%$ & $88.30 \%$ & $\mathbf{9 8 . 0 0 \%}$ \\
\hline
\end{tabular}

TABLE 2

COMPARISON BETWEEN CROSS-VALIDATED CORRELATION FOR EACH TYPE OF MODELS

\begin{tabular}{|c|c|c|c|c|}
\hline Properties & UCS & PR & IFC & PHIE \\
\hline Spherical & $98.10 \%$ & $92.40 \%$ & $99.30 \%$ & $92.00 \%$ \\
\hline Gaussian & $\mathbf{9 9 . 0 0 \%}$ & $\mathbf{9 7 . 4 0 \%}$ & $\mathbf{9 9 . 6 0 \%}$ & $\mathbf{9 1 . 2 0 \%}$ \\
\hline Exponential & $96.00 \%$ & $93.20 \%$ & $99.10 \%$ & $\mathbf{9 5 . 0 0 \%}$ \\
\hline
\end{tabular}

Clearly, these correlation factors (r2) for variogram models are similar to each other. The best-fit variogram had the highest $r 2$ (in bold). The calculation results were summarized in table 3 .

In table 3 , the variogram models for UCS, PR and IFC were Gaussian. It means that there was a high correlation over short range and these were continuous phenomena. Where as, the PHIE variogram model was Exponential, which means this had a short scale variability.

As also in Table 3, these variogram had a good correlation coefficient $(\mathrm{r} 2)$. These greatly good $\mathrm{r} 2$ $(>95 \%)$ of all variogram models and crossvalidations showed that these chosen variogram models are greatly accurate.
TABLE 3

SUMMARY OF CORRELATION COEFFICIENT OF VARIOGRAM MODELS

\begin{tabular}{|c|c|c|c|c|}
\hline Properties & UCS & PR & IFC & PHIE \\
\hline $\begin{array}{c}\text { Variogram } \\
\text { Model }\end{array}$ & Gaussian & Gaussian & Gaussian & Exponential \\
\hline $\begin{array}{c}\text { Cross- } \\
\text { validation } \\
\text { r2 }\end{array}$ & $99 \%$ & $97.4 \%$ & $99.6 \%$ & $95 \%$ \\
\hline
\end{tabular}

TABLE 4

SUMMARY OF CORRELATION COEFFICIENT (r2) OF XX-4P GEOMECHANICAL MODEL

\begin{tabular}{|c|c|c|c|c|}
\hline Properties & UCS & PR & IFC & PHIE \\
\hline r2 & $\mathbf{7 7 . 7 3 \%}$ & $58.5 \%$ & $\mathbf{9 4 . 1 9 \%}$ & $\mathbf{8 8 . 1 3 \%}$ \\
\hline
\end{tabular}

In Table 4, the correlation coefficient (r2) of all properties are fairly high, roughly $80 \%$. However, Poisson's ratio (PR) with $\mathrm{r} 2=58.5 \%$ may be due to lack of solid actual data for calibration.

\section{DISCUSSION}

There were just two wells used in calculating variograms which are applied isotropic analysis. If more wells were used, anisotropic variograms would have been calculated and compared with isotropic ones to select the best-fit variogram, resulting more accurate models.

The log-derived rock strengths should be calibrated by more rock test data to initiate better accuracy. So that, the predicted model will minimize the uncertainties of consequent geomechanics application, particularly in well bore stability.

The results could be sustainably improved if the data was coupled with sedimentary analysis and diagenetic classification using a couple of new computing methods such as fuzzy logic, Artificial Neural Network (ANN).

\section{REFERENCE}

[1] R. Gonzalez, K. Schepers, S.R. Reeves, Integrated Clustering/ Geostatistical/ Evolutionary Strategies Approach for 3D Reservoir Characterization and Assisted History-Matching in a Complex Carbonate Reservoir, SACROC Unit, Permian Basin, SPE 113978. 2008.

[2] A. Khaksar, P.G Taylor, Z. Fang, Rock Strength from Core and Logs. 2009.

[3] William L. Power, Toru Sano, Kiam Chai Ooi, David Andrew Castillo, Marian Magee, Katharine Burgdorff, "Insitu Stress and Rock Strength in Rang Dong Field - 
Off shore Vietnam - Implications for Drilling in Basement Rocks," in IADC/SPE Asia Pacific Drilling Technology Conference and Exhibition, Ho Chi Minh City, Vietnam, 2010

[4] Asadi, M.S Khaksar, White, A. Challenge in defining fracture gradient for highly deviated wells in the presence of natural frectures in deep water enviroments. ARMA 14-7010. 48th US rock mechanics/geomechanics symposium. USA June 2014.

[5] N. V. Thuận, Luận văn tốt nghiệp. Hồ Chí Minh, 2015.

[6] Lâm Hoàng Quốc Việt, Trà Thanh Sang, Tạ Quốc Dũng, Úng dụng địa thống kê xác định vùng phân bố tầng chứa nước Pleistocen trên (qp3) tỉnh Hậu Giang. 2014.

[7] E.H. Isaaks, R.M. Srivastava, An Introduction to Applied Geostatistics. Oxford: Oxford University Press, 1989.

[8] Clark, I. Harper, Practical Geostatistics. Ecosse North Ameria, 2000.

[9] Clark, I. Harper, Practical Geostatistics. Ecosse North Ameria, 2000.

[10] Mohan Kelkar, Godofredo Perez, Applied Geostatistics for Reservoir Characterization. New York, 2002.

[11] Deutsch, Clayton V., Geostatistical Reservoir Modeling. 2002.

[12] Nguyễn Hiệp, Nguyễn Văn Đắc, Địa chất và tài nguyên dầu khí Việt Nam. 2007.

Ta Quoc Dung PhD., Geomechanics Specialist. He graduated with bachelor degree in Petroleum engineering from Ho Chi Minh City University of Technology - VNU-HCM in 1997. He received his aster degree in applied mechanics in Drilling Engineering from Liege University in 2004 and $\mathrm{PhD}$ degree in Petroleum Engineering from The University of Adelaide, Australia in 2010. He worked more than 20 years in different academic positions at Ho Chi Minh City University of Technology - VNU-HCM and supervised more than 40 s honored projects and $10 \mathrm{~s}$ MSc students. He has been involved in training and significantly consulting for several oil and gas companies operated in Vietnam. For the last 10 years he participated in various $G \& G$ projects, geomechanics projects in certain Vietnamese offshore fields. Dr. Ta Quoc Dung has expertise in Coupled reservoir simulation and Geostatistics applications. He currently is Dean, Faculty of Geology and Petroleum engineering at Ho Chi Minh City University of Technology - VNUHCM.
Vu Duc Thinh was born in Lagi Town, Binh Thuan Province, Vietnam in 1996. He enrolled as a first-year student of Petroleum Engineering in Ho Chi Minh City University of Technology VNU-HCM (HCMUT) in 2014. From September 2017, he has been studying Petroleum Engineering at Politecnico di Torino - Italy as an international exchange student.

From 2015, he has been a Research Assistant for the Faculty of Geology and Petroleum Engineering in Ho Chi Minh City University of Technology VNU-HCM. From 2015 to 2017, he was a Teaching Assistant for the articulation program with University of Adelaide- Australia for three Petroleum Engineering courses. He is the coauthor of two articles. His research interests include Geostatistics applications in exploration, drilling and production. 


\title{
Úng dụng địa thống kê dự đoán phân bố không gian của thuộc tính địa cơ trong lĩnh vực dầu khí
}

\author{
Tạ Quốc Dũng, Vũ Đức Thịnh
}

Tóm tắt—Các ứng dụng của địa co học có một vai trò rất quan trọng trong kỹ thuật dầu khí bao gồm nhiều ứng dụng trong tìm kiếm thăm dò, khoan, khai thác, hoàn thiện và phát triển mỏ. Một số các thông tin thường được yêu cầu tính toán như hệ số nén một trục UCS, hệ số Poisson, hệ số ma sát trong, độ rống... Để ước lượng các thông số này, có nhiều phương pháp truyền thống được sử dụng. Tuy nhiên, phương pháp địa thống kê đang được áp dụng rộng rãi trong lĩnh vực dầu khí vì có nhiểu ưu điểm vượt trội. Các kết quả của nghiên cứu này đã đưa ra cách tính các thông số địa cơ 1D từ hai giếng đã khoan (XX2P và XX3P) bằng các mối tương quan thực nghiệm đang được sử dụng. Từ các thông số địa cơ thu được, phương pháp địa thống kê được ứng dụng để xây dựng và lực chọn mô hình variogram phù hợp và phân tích tính liên tục trong không gian $2 \mathrm{D}$ của mặt cắt giữa 2 giếng. Sau đó, phương pháp Ordinary-Kriging $(\mathrm{OK})$ được sử dụng để nội suy các thông số cho cho không gian giữa 2 giếng dữ liệu và sau đó trích xuất các kết quả nội suy một giếng sắp khoan XX4P. Các giá trị nội suy được so sánh với giá trị thực đo tại giếng sau khi khoan dựa trên hệ số tương quan. Hầu hết các hệ số này có giá trị gần bằng 1 chứng tỏ mô hình nội suy có độ chính xác cao và đáng tin cậy. Các kết quả tính toán của mô hình này có thể được sử dụng để dự báo các mô hình địa cơ cho các giếng sắp khoan khác trong vùng lân cận và ứng dụng kết quả dự báo trong tính toán ổn định thành giếng hoặc nghiền cứu khả năng sinh cát của giếng khai thác.

Tù khóa-Địa thống kê, variogram, kriging, mô hình địa cơ học, ổn định thành giếng. 